\section{SEX EDUCATION AND GUIDANCE AN EDUCATIONAL PROBLEM}

\section{By DR. R. SUTHERLAND}

Medical Adviser, Central Council for Health Education

GEXUAL intercourse outside marriage is generally $D$ regarded as a breach of our moral code. It is impossible therefore to gauge exactly the extent to which it is occurring, but the extra-marital conceptions and venereal disease infections which often result from it are some measure of its frequency. Roughly a hundred thousand of the children born in Great Britain during 1938 were conceived outside marriage, and during the same year there were at a rough estimate forty-seven thousand new cases of venereal disease. Not every sex adventure leads to conception, however, and the patients who have contracted venereal disease from their first illicit intercourse are very much in the minority. Consequently, extra-marital intercourse must be by no means uncommon.

There is little doubt that war conditions have led to a further slackening of moral standards. Family life has been disrupted, young people are far from the restraining influence of home, and life for many has become less sure. It is not surprising, therefore, that last year the number of new cases of venereal disease in Great Britain increased to roughly seventy thousand among civilians alone. Apart from its sig. nificance as an indication of spreading moral laxity, this increase affects the war effort, the health and happiness of the community, and the welfare of innocent spouses and unborn children.

The Minister of Health has recognized that this problem must be tackled and has had the courage to initiate a campaign to break down the taboo that has in the past so sadly interfered with the attack on venereal diseases. His Chief Medical Officer, Sir Wilson Jameson, made history by speaking frankly of the venereal disease menace in a radio talk last year ; and the Ministry of Health is now collaborating with the Central Council for Health Education in giving widespread publicity to the facts about venereal disease through advertisements which are to appear for the next six months in the national and provincial newspapers. The Ministry and the Central Council have also arranged for film and poster displays, and the Central Council has produced a variety of leaflets for distribution to the public.

If the campaign of public education is to be successful, however, there must be an honest examination of all aspects of the problem as well as a free and frank discussion of the nature, methods of spread, and signs and treatment of the disease. This has been recognized by the Central Council for Health Education, which has been charged by the Ministry of Health with the responsibility for the central provision of education in this as in other health matters. Accordingly, on February 26, the Central Council held a conference in London which was attended by more than a thousand representatives and medical officers of English and Welsh local authorities, and at which the various methods of approaching the problem were freely discussed by a large number of speakers, among whom were the Archbishop of Canterbury (president of the Central Council), and the Minister of Health. This conference, sitting under the chairmanship of Dr. Charles Hill, chairman of the Central Council, should be of the greatest value in helping the churches, the Ministry, the Central Council, and local authorities to work out the agreed. and co-ordinated national educational policy, which the Minister of Health urged is needed.

As the Archbishop of Canterbury said, the problem is only partly medical because spiritual, moral and social considerations are involved (see also NATURE, 150,$529 ; 1942$ ). The Archbishop went on to say that the moral element is the most important and should have the first attention. At a similar conference held in Scotland the following week, however, the Moderator of the General Assembly of the Church of Scotland maintained that the medical problem should be dealt with at the same time as the moral problem. In this he was supported by the Secretary of State for Scotland.

The need for developing the moral approach is generally accepted, but dispute rages hotly over the extent to which a purely medical or epidemiological approach to the problem can be justified. All are agreed that venereal disease could be practically ended if all extra-marital intercourse were avoided.

The difficulty is that the sexual urge, upon which the spread of venereal disease depends, is one of the most powerful primitive instincts, and that, as the figures for extra-marital conceptions and new cases of venereal disease show, the moral forces and social measures so far at work have signally failed to keep it fully under control. On the other hand, it must be recognized that, however successful it might be in dealing with the epidemiological problem of venereal disease, a medical approach which largely neutralized moral teaching and encouraged promiscuity might in the long run do more harm than good. This is what the Archbishop fears. Are his fears justified?

In the past, the moral attack on lax sex conduct, and consequently on venereal disease, has been greatly handicapped by the public attitude towards sex education. We can now look forward, however. to rapid developments in this field. Children and young people should be brought up to a full knowledge of their own bodies and of those of the opposite sex. Sex should be a mystery no longer, and it should cease to be associated in the child's mind with the naughty and the furtive. The child's innocent curiosity about sex should be satisfied naturally as it arises; and, before he becomes emotionally involved at adolescence, he should understand his own body, the workings of sex, and the moral and social reasons for self-control and continence. The spiritual teachings of the churches would thus be immensely strengthened by an enlightened selfinterest which would encourage the youth to defer immediate satisfaction in the interests of adult happiness and of his future home and family. The stress should be on pride in chastity rather than upon fear of the possible consequences of promiscuity. Information about the venereal diseases should therefore be given naturally as part of instruction in the communicable diseases. Although all the basic information should have been given before puberty, the emotional problems of the adolescent should be sympathetically discussed at the time when they are likely to arise. The educators, whether teachers or youth leaders, must themselves be taught, and the Central Council for Health Education is prepared to give this instruction if asked to do so by local authorities.

There must, however, be a social approach to the problem as well. The demands made upon selfcontrol must appear reasonable and the rewards fairly certain and not too distant. Conditions of 
employment and of housing must therefore offer the prospect of early marriage. As the Archbishop said, young people must have ample opportunity of enjoying each other's company in innocent activities amidst pleasant surroundings.

We must not disregard the assaults upon youthful self-discipline that are constantly being made by erotic magazines, books, films, and revues, and by aleohor.

When we come to consider the medical, or epidemiological, approach we are on much more controversial ground. Nevertheless, "the wages of sin is death" policy is almost universally out of fashion, and all are agreed that there must be adequate and convenient facilities for the early treatment of those who have not been continent and have as a consequence developed the first manifestations of venereal disease. Differences of opinion appear when the logical epidemiologist asks why we should wait until infection has actually taken place before starting treatment. He contends that the medical treatment of the problem should begin immediately the spiritual, moral, and social approach has failed; that is, as soon as any individual has succumbed to the temptation to extra-marital intercourse. He maintains that hundreds of thousands are exposing themselves to infection each year and that we must not just leave them to their fate. To do so involves not only great mental distress, some disability, and much trouble and expense, but often exposes innocent people to the risk of infection. $\mathrm{He}$ therefore urges that all young people should be informed of the preventive measures which will very largely reduce the chances of infection if a risk is taken. These measures include the use of a condom as a mechanical barrier to the passage of the germs, self-treatment by thorough washing and chemical applications to the parts immediately after exposure, and in addition, or alternatively, attendance at a treatment centre as soon as possible for prophylactic treatment by experts.

If there were only the narrow medical problem of venereal disease to be considered, this course would undoubtedly be the correct one, and its general application would soon reduce these diseases to relatively negligible proportions. Not one case of venereal disease has occurred, for example, among tens of thousands of persons who received prophylactic treatment at a treatment centre within twenty-four hours of exposure to the risk of infection. But the Archbishop considers that instruction on prophylaxis would be bound to have an adverse effect upon the reaction of the young to spiritual and moral teaching. If he is right in thinking that prophylactic teaching would inevitably amount in effect to incitement to fornication, then obviously the epidemiological arguments in favour of such teaching must be disregarded. But is he right? Is it in fact impossible to find teachers who could combine the moral and medical approach in such a way as to inspire high ideals of sex conduct, while yet openly recognizing that the flesh is sometimes weak and that some of the pupils may succumb to temptation, and should at least protect themselves from disease? Are we not deceiving ourselves if we fail to recognize that, however good and undiluted the moral teaching may be, it will fail in many cases? Need a realistic recognition of this fact necessarily mean an increased number of failures?

Surely the time has come to convert this no-man'sland upon which this moral versus medical controversy is raging into a common ground on which the moralists, the educationists, and the medical men can meet to try to work out an agreed venereal disease policy which will improve our national moral standards at the same time as it reduces the incidence of venereal disease. The Central Council for Health Education has made a beginning by providing a platform for the free exchange of views on this important question. It now only remains for the various schools of thought to resolve their conflict and work together in this great cause.

\section{OBITUARIES}

\section{Prof. J. Eustice}

Prof. John Eustice, late head of the Faculty of Engineering in University College, Southampton, was the son of a Cornish mining engineer. He was trained first at the School of Mines, Camborne, and then at the Royal College of Science; he was a Whitworth Scholar and a National Science Scholar.

In 1891 he became lecturer in engineering to the Hampshire County Council, and in the next year joined the Hartley College, Southampton, where he formed its engineering side. For forty years he built up the Engineering Department until his retirement in 1931. By that time he had developed courses for the external B.Sc. degree in engineering of the University of London and also an active system of part-time and evening instruction for the apprentices and employees of engineering firms in the district. The difficulties of this development must have been very great, and to one who relieved him on his retirement the marvel was that he had achieved so much with so little equipment and accommodation. In addition to the technical instruction, he kept in his own hands the large administrative work of the evening classes as they grew up.

Prof. Eustice could find little time for research, but he did make a very beautiful study of the flow of liquids in curved pipes. The system of showing coloured stream lines in laminar flow had been used by Osborn Reynolds and Hele Shaw, but Eustice adapted the same general method to show the complicated three-dimensional pattern in which the stream lines interweave as flow passes round a curved tube.

On his retirement at the age of sixty-seven, Prof. Eustice was thoroughly tired out, but he had two great assets : great love of his church and all connected with it; and a keen interest-and a good performance-in golf. He changed to the new conditions with remarkable success, and his retirement must have been very happy. His activity and good health lasted to within a few days of his death on February 24 in his seventy-ninth year.

T. R. CAve-Browne-Cave.

WE regret to announce the following deaths:

Mr. Joseph Bunny, late of the Nigerian Forestry Service, on March 9.

Dr. C. N. Haskins, Chandler professor of mathematics at Dartmouth College, U.S.A., on November 14, aged sixty-eight years.

Mr. R. W. Sayles, research associate of the Division of Geology, Harvard University, on October 23, aged sixty-four. 